\title{
Effectiveness of the Art of Living YES+ Programme on College Students
}

\author{
Sweta Sharadkumar Chauhan ${ }^{1}$
}

\section{ABSTRACT}

During Examination sports and entrance tests Peer Pressure is very much common. It is experienced in human relations too. So how can we cope with everything? The Art of Living YES $^{+}$(The Youth Empowerment Seminar) programme is a life skills programme. It is composed of three modules: Healthy Body, Healthy Mind and Healthy Lifestyle. The Art of Living YES ${ }^{+}$ Programme is based on- Sudarshan Kriya, Meditation and breathing techniques, Techniques for mental focus and concentration, Techniques for overcoming fear and anxiety, Interactive process, team games, Food awareness, Group discussions, Learning through fun and games, service to others, confidence building and leadership. The researcher developed a rating scale for measuring $\mathrm{YES}^{+}$programme. Post test only experimental group design was used in this research. The students of IRMA (Institute of Rural Management), Anand made the population for the study. For content analysis $\mathrm{X}^{2}$ was found out and interpretation is derived from the result.

College students have shown positive tendency about $\mathrm{YES}^{+}$programme. It is suggested that such progammes can be implemented on various groups at colleges and in higher education to enhance the positive life skills and better living and life style.

Keywords: Effectiveness, the Art of Living YES+ Programme, College Students

During Examination sports and entrance tests Peer Pressure is very much common. It is experienced in human relations too. So how can we cope with everything?

The Art of Living $\mathrm{YES}^{+}$( The Youth Empowerment Seminar) programme is a life skills programme. It is composed of three modules: Healthy Body, Healthy Mind and Healthy Lifestyle.

One of the key characteristics of the educational programs offered by the foundation is giving practical knowledge, techniques and skills that help people cope with stress and stressful situation, remove their influences and handle more efficiently with different tasks and demands in daily life, while at the same time improving health and achieving better quality of life.

${ }^{1}$ Assist. Professor, Bavisgam B.Ed. College, Sardar Patel University, Vallabh Vidyanagar (C) 2015 I S Chauhan; licensee IJIP. This is an Open Access Research distributed under the terms of the Creative Commons Attribution License (http://creativecommons.org/licenses/by/2.0), which permits unrestricted use, distribution, and reproduction in any Medium, provided the original work is properly cited. 


\section{- The Art of Living Foundation:}

"My Vision is a Stress-free, Violence free world"

\section{- Sri SriRavishankar}

Sri SriRavishankarji is a humanitarian and spiritual leader, an ambassador of peace and human values. He found The Art of Living Foundation, one of the largest international non-government organizations through his work; Sri Sri has inspired millions of people around the world with a vision of a stress-free, violence-free world. He has founded courses that provide techniques and tools to live a deeper, more joyous life and he has established nonprofit organization that recognize a common human identity above the boundaries at race, nationality and religion.

\section{THE ART OF LIVING YES ${ }^{+}$PROGRAMME:}

$\mathrm{YES}^{+}$is a programme based on life skills. It is composed of three modules:

- Healthy Body

- Healthy Mind

- Healthy Lifestyle

\section{-Healthy Body:}

The health body module consists of physical activity that includes yoga stretches, mindful eating processes and interactive discussions about food and nutrition.

\section{-Healthy Mind:}

The healthy mind module includes stress management and relaxation techniques. Breathing exercises (eg.,SudarshanKriya) and mindfulness techniques are used to calm the mind, bringing awareness to the moment and enhancing concentration. Group processes promote personal responsibility respect, honesty, and service to others.

\section{-Healthy Lifestyle:}

In the healthy Lifestyle module students learn strategies for handling challenging emotional and social situations, especially peer pressure. Mindful decision making and leadership skills are taught via interactive games come and see the world from a different point of view.

\section{YES $^{+}$PROGRAMME CONTENTS:}

The Art of Living YES ${ }^{+}$Programme is based on- SudarshanKriya, Meditation and breathing techniques, Techniques for mental focus and concentration, Techniques for overcoming fear and anxiety, Interactive process, team games, Food awareness, Group discussions, Learning through fun and games, service to others, confidence building and leadership. 


\section{Overview of the Programme:}

-Age Group : : : : $\quad$ : 30 Years

-Course duration : :4 to 6 days

-Time Per day :3 to 4 hours.

\section{RESEARCH QUESTIONS:}

-What is $\mathrm{YES}^{+}$programme?

-How could the YES ${ }^{+}$Programme be useful for students?

-What will be the effect of $\mathrm{YES}^{+}$Programme on student's behavior?

\section{OBJECTIVES OF THE STUDY:}

-To construct rating scale for measuring $\mathrm{YES}^{+}$programme.

-To try-out $\mathrm{YES}^{+}$programme in college.

-To study the effectiveness of $\mathrm{YES}^{+}$programme through quantitative analysis.

-To derive educational implications and make recommendation for $\mathrm{YES}^{+}$programme.

\section{Research Methodology:}

-YES ${ }^{+}$programme was applied by Art of Living teacher.

-The researcher developed a rating scale for measuring $\mathrm{YES}^{+}$programme. The data was collected and processed by statistical analysis and interpretations are derived.

-Post test only experimental group design was used in this research.

\section{Population and Sample:}

The students of IRMA (Institute of Rural Management), Anand made the population for the study. 40 students were given a rating scale. This was a sample for the study. which was random representative sample.

\section{Construction of a Tool:}

The researcher had constructed a rating scale comprised of Attributes. After expert's opinions ten attributes were included in this rating scale. The rating scale was administered on students after the programme.

\section{Statistical Data Analysis:}

For content analysis $\mathrm{X}^{2}$ was found out and interpretation is derived from the result. 
Effectiveness of The Art of Living YES+ Programme on College Students

\section{College students understanding about $\mathrm{YES}^{+}$programme}

\begin{tabular}{|l|l|l|l|l|l|l|l|l|}
\hline No. & Attributes & A & B & C & D & $\mathbf{E}$ & $\mathbf{X}^{\mathbf{2}}$ Value & Sign. \\
\hline 1. & SudarshanKriya & 25 & 14 & 01 & 00 & 00 & 62.74 & $* *$ \\
\hline 2. & Peace of Mind & 25 & 10 & 04 & 01 & 00 & 52.74 & $* *$ \\
\hline 3. & Patience & 19 & 14 & 06 & 01 & 00 & 34.24 & $* *$ \\
\hline 4. & Satisfaction & 24 & 10 & 04 & 02 & 00 & 47 & $* *$ \\
\hline 5. & Leadership & 25 & 11 & 03 & 01 & 00 & 54.48 & $* *$ \\
\hline 6. & Creativity & 23 & 10 & 05 & 02 & 00 & 42.24 & $* *$ \\
\hline 7. & Dynamism & 20 & 14 & 04 & 02 & 00 & 37 & $* *$ \\
\hline 8. & Team Work & 22 & 12 & 05 & 01 & 00 & 41.74 & $* *$ \\
\hline 9. & Life Style & 24 & 10 & 05 & 01 & 00 & 47.74 & $* *$ \\
\hline 10. & Efficiency & 25 & 08 & 05 & 02 & 00 & 49.74 & $* *$ \\
\hline
\end{tabular}

*indicates significance at 0.05 level.

**does not indicate significance at 0.05 level

$\mathrm{df}=4$, at 0.05 level sign.value is 9.488 .
$\mathrm{A}=$ Strongly Agree
$\mathrm{B}=$ Agree
$\mathrm{C}=$ Uncertain
$\mathrm{D}=$ Disagree
$\mathrm{E}=$ Strongly Disagree.

For the attributes 1 to 10 the value of $X^{2}$ at $\mathrm{df}=4$ and at 0.05 level the calculated $\mathrm{X}^{2}$ value $>$ table value. Hence it can be said that difference is significant. The null hypothesis is rejected. So the data is not normally distributed.

From above analysis it could be interpreted that the college students had not given their choice at random. Hence specific opinions on positive $\mathrm{YES}^{+}$programme are generated from their chosen frequencies.

\section{FINDINGS OF THE STUDY:}

-The college students' responses for the attributes of rating scale has generated specific opinions. Their level of understanding about Yes ${ }^{+}$programme from statistical interpretation of $\mathrm{X}^{2}$ is showing general choice about attributes.

- College students have shown positive tendency about YES ${ }^{+}$programme. 


\section{CONCLUSION:}

The Art of Living YES ${ }^{+}$programmeare based on unique approach, process of social interaction, the use of breath as a link between human mental state and situation they face. Students were more positive. $\mathrm{YES}^{+}$programme was found more effective on the students of IRMA.

It is suggested that such progammes can be implemented on various groups at colleges and in higher education to enhance the positive life skills and better living and life style.

\section{REFERENCES}

Andrej Trampur, MajaTrampuz, R.P. Research on the effects of The Art of Living anti-stress program. The possibility of their contribution to managing stress in the slovenian armed forces.

\section{Websites}

www.artofliving.org. www.jahonline.org. 